Original Scientific Article

\title{
TWO POSSIBILE HORMONAL TREATMENT METHODS FOR INDUCING FOLLICULAR GROWTH IN DAIRY COWS WITH INACTIVE-STATIC OVARIES
}

\author{
Branko Atanasov, Ljupco Mickov, Igor Esmerov, Ksenija Ilievska, \\ Martin Nikolovski, Toni Dovenski
}

\author{
Ss. Cyril and Methodius University, Faculty of Veterinary Medicine - Skopje, \\ Institute of Reproduction and Biomedicine, Skopje, R. Macedonia
}

Received 25 June 2014; Received in revised form 18 August 2014; Accepted 29 August 2014

\begin{abstract}
Postpartum anestrus is a physiological phenomenon in high-producing dairy cows. Static ovaries have been related as major contributors for its occurrence causing a significant reproductive problem to the dairy industry. Different treatment methods have been employed with inconsistent rate of success in initiation of cyclicity, requiring further investigations in order to achieve satisfactory results. The aim of the present study was to compare the ovarian response in cows diagnosed with static ovaries, more than 60 days postpartum using two different hormonal treatment (GnRH and eCG) methods. A total of 58 acyclic cows (no CL, follicles $<8 \mathrm{~mm}, \mathrm{P} 4<0.5 \mathrm{ng} / \mathrm{mL}$ ) were randomly divided into three groups: $\mathrm{GnRH}$ (Group 1, n=23), eCG (Group 2,

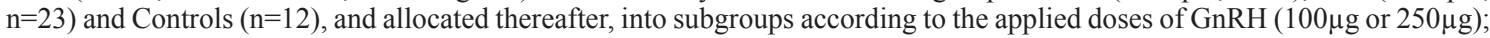
eCG (750 IU or $1000 \mathrm{IU})$ whilst control group cows were left untreated. Daily follicular growth rate and treatment respond interval were estimated based on repeated ultrasound examinations. Blood serum P4 sampling was done on d -7, d-0 (start of the experiment) and on d 7 after ovulation. Resumption of cyclic activity occurred in $55.17 \%(32 / 58)$ of the treated cows, $56.52 \%$ in Group 1; $60.86 \%$ in Group 2 and $41.66 \%$ in the control group. Overall, the follicular growth rate was similar between the trials group and significant with regard to the cows in the control group $(p<0.05)$. eCG or GnRH treated cows responded significantly faster $6.85 \pm 0.2$ and $7.84 \pm 0.2$ days, respectively, in comparison to the control group cows ( $17 \pm 0.7$ days, $\mathrm{p}<0.001)$. Treatment with a single dose of GnRH or eCG caused resumption of follicular growth and ovulation following luteogenesis (forming CL) without significant changes in P4 concentrations on day 7 after ovulation ( $p>0.05$ ). Cows in Group 2 had significantly higher incidence of multiple ovulations than cows in Group $1(\mathrm{p}<0.05)$. The eCG treatment resulted in a faster response and higher ovulation rate compared to GnRH treatment. In conclusion, both treatments have shown acceptable results in resumption of cyclicity in dairy cows with static ovaries.
\end{abstract}

Key words: true anoestrus, ovary, GnRH, eCG, dairy cow

\section{INTRODUCTION}

The early resumption of estrous cycles following parturition in dairy industry has a great impact in reaching high reproductive efficiency (27). Anestrus is a physiological state during the postpartum period in high-producing dairy cows, with major economic implications since it increases the length of the

Corresponding author: Prof. Toni Dovenski, $\mathrm{PhD}$

E-mail address:dovenski@fvm.ukim.edu.mk

Present address: Department of Reproduction,

Faculty of Veterinary Medicine, Skopje,

Ss. Cyril and Methodius University in Skopje

Lazar Pop Trajkov 5-7, Skopje, Macedonia

Phone: +38970258989; Fax. +38923114619

Copyright: (C) 2014 Atanasov B. This is an open-access article published under the terms of the Creative Commons Attribution License which permits unrestricted use, distribution, and reproduction in any medium, provided the original author and source are credited.

Competing Interests: The authors have declared that no competing interests exist.

Available Online First: 15 September 2014

http://dx.doi.org/10.14432/j.macvetrev.2014.09.023 calving interval (17). In general, a calving interval of 12-13 months is considered economically optimal for dairy cows (25). In order to achieve such a calving interval, a post-partum cow has to resume ovarian activity and conceive within 85 days after calving (24). Santos et al. (30) reported that in highproducing Holstein herds, $6-59 \%$ of the postpartum cows have not resumed cyclicity by Day 60 after calving. Furthermore, cows that have not ovulated in the first 4- 8 weeks after calving or not been observed in estrus during the first $60 \mathrm{~d}$ postpartum (classified as anovular or anestrual (12), respectively), have a significantly higher risk of being culled than cows that ovulated or have displayed estrus (25).

In the cycling cows, ovarian follicular growth occurs in a regular wavelike pattern. Each wave is comprised of successive phases referred to as recruitment, selection, deviation, dominance, and atresia (20). Trans-rectal ultrasound monitoring 
of the ovarian follicles reveals that most estrous cycles in cows have two or three follicular waves $(11,33)$. The follicular waves are first detectable at $4-5 \mathrm{~mm}$ follicles approximately on $\mathrm{d} 0$ and $\mathrm{d} 10$ for two-wave and on d 0,9 and 16 for three-wave inter-ovulatory intervals (11). During each wave, 7-11 small follicles (4 $\mathrm{mm}$ in diameter synchronously enter a common growth phase of about 3 days (10). Following that period, a follicular deviation transpired characterized by dissociation in growth rates and the distinction between the future dominant and subordinate follicles (10), resulting in dominant follicle which will attain an ovulatory diameter (10). The latter suppresses the growth of subordinate follicles, thus preventing the emergence of a new follicular wave (2). Each follicular wave is stimulated by a transient increase in the follicle stimulating hormone (FSH) secretion (1) caused by the regression of the dominant follicle of the previous wave (10). The dominant follicle subsequently acquires luteinizing hormone (LH) dependency for its own continued growth and suppresses FSH secretion, therefore starving the subordinate follicles of sufficient FSH support $(1,10)$. Upon luteal regression and declining of progesterone (P4), follicular maturation associated with increased estradiol synthesis occur, which trigger a LH surge that causes ovulation of a dominant follicle (18).

Subestrus, cystic ovarian disease, static ovaries (true anestrus) and persistent corpus luteum are the four clinical forms of anestrus reported that impediment the reproductive efficiency (36). Among all, static ovaries defined as ovaries with follicles $<8 \mathrm{~mm}$, absence of corpus luteum (CL) and $\mathrm{P} 4$ concentration $<0.5 \mathrm{ng} / \mathrm{mL}$ between two consecutive ultrasound examinations 7-10 days apart $(7,17)$, stands as one of the major ovarian dysfunction in the early postpartum period. The physiology underlying their occurrence still remains unclear, although according to Arthur's 1989 (3), the reasons might be two-fold: either insufficient secretion of gonadotropins for encouraging the folliculogenesis or the inability of the ovaries to respond to gonadotropins. Wiltbank et al. (34) reported that the absence of ovarian follicles larger than $8 \mathrm{~mm}$ in diameter may be observed in animals subjected to severe nutritional restriction. The latter is associated with the absence of pulsatile LH release (14). Different treatment methods for static ovaries treatment have shown inconsistent rate of success in the resumption of ovarian cyclicity, imposing further investigations to achieve satisfactory results (28).

The current study was designed to test the hypothesis that single GnRH (gonadotropin releasing hormone) or eCG (equine chorionic gonadotropin) injection will have influence on the ovarian follicular dynamics in cows diagnosed as being in true anestrous in a dose-dependent manner. Therefore, the objectives of the present study were to evaluate the possibility of inducing follicular growth in cows diagnosed with static ovaries using different doses of single GnRH and eCG injection.

\section{MATERIALS AND METHODS}

\section{Animals and study design}

Holstein-Friesian cows from three commercial dairy farms in the Republic of Macedonia were involved in the experiment. In Dairy A, cows were housed in a tie-stall on deep straw bedding, whereas in Dairies B and C cows were housed in a free stall with cubicles. On each farm cows were milked twice daily (morning and the afternoon) with average lactation of $6500 \mathrm{~kg}, 6100 \mathrm{~kg}$ and $6400 \mathrm{~kg}$ per 305 days, on Dairy A, B and C, respectively. Of the 298 routinely examined cows using trans-rectal ultrasonography, 67 cows were identified as having inactive ovaries (no CL, follicles $<8 \mathrm{~mm}$, and $\mathrm{P} 4$ $<0.5 \mathrm{ng} / \mathrm{mL}$ ). To verify that no follicular growth in aforementioned cows transpired, 7 days later (referred as $\mathrm{d} 0=$ start of the experiment) another ultrasonic examination as well as the blood serum P4 determination was performed. Follicles larger than $>10 \mathrm{~mm}$ were recorded in 9 cows and these cows were excluded from further analysis resulting in 58 cows enrolled in the study. Cows were randomly assigned into three groups: GnRH (Fertagyl, Intervet-Holland $)=$ Group $1(\mathrm{n}=23)$, eCG (Folligon, Intervet-Holland $=$ Group $2(n=23)$ and Control $(n=12)$ cows that were left untreated. Treated cows were further allocated into two subgroups (SB) per treatment according to the applied doses of; for GnRH-treated group, the SB $1.1(\mathrm{n}=8)$ was treated with $100 \mu \mathrm{g}$ and SB $1.2(\mathrm{n}=15)$ with $250 \mu \mathrm{g}$ $\mathrm{GnRH}$; for the eCG- treated group, the SB 2.1 $(n=8)$ was treated with 750 IU and SB $2.2(n=15)$ with 1000 IU eCG. Trans-rectal ultrasonographic monitoring of the follicular dynamics was done on a daily basis, starting from d 0 until ovulation (defined as disappearance of the largest follicle between two consecutive ultrasound examinations) and once on $\mathrm{d} 7$ after ovulation to confirm presence of the corpus luteum in cows which experienced follicular growth. In cows that failed to resume regular folliculogenesis the ultrasound examination was performed simultaneously as the cows which establish cyclicity and continue every third day until 110 DIM. Daily follicular growth rate and treatment 
Two possibile hormonal treatment methods for follicular growth in cows with inactive-static ovaries

respond interval were estimated in all groups using the following definitions: Daily growth rate (GR, $\mathrm{mm} /$ day) - the difference between the largest and the smallest diameter of a follicle divided by the number of days; Treatment respond interval (days) - number of days from the first visualization of the follicle until the follicle reached pre-ovulatory size.

\section{Ultrasonographic examination}

Monitoring of the follicular dynamics was done by transrectal ultrasonography of the ovaries using B-mode ultrasound machine Aloka SSD 500, (Tokyo, Japan) equipped with rectal linear $7.5 \mathrm{MHz}$ transducer, connected with a printer, so that images of each ovary could be taken daily. Before insertion of the lubricated transducer, the rectum was emptied, and the ovaries were first manually located. During each examination and using the prints taken during the ultrasound, ovarian maps were drawn to record the size and relative position of the follicles. The diameters of the follicles were obtained from two linear measurements taken at right angles by means of electronic calipers located on the ultrasound device using the images on which the diameters of the follicles were maximal.

\section{Blood progesterone analysis}

Blood samples were collected on $\mathrm{d}-7, \mathrm{~d} 0$ and $\mathrm{d} 7$ after ovulation from the coccygeal vein into glass tubes and centrifuged (3000 rpm x $g 10$ minute) within 3 hours after collection. The samples were stored at $-20^{\circ} \mathrm{C}$ until determination of progesterone by enzyme-immune assay (EIA) was performed. The determination was done at the laboratory of endocrinology at the Faculty of Veterinary Medicine - Skopje (Macedonia), using a commercially available kit (HUMAN, Progesterone ELISA Test Germany). The intra- and inter-assay coefficients of variation were $<10 \%$. The lower detection limit was $0.07 \mathrm{ng} \mathrm{ml}^{-1}$.

\section{Statistical analysis of the data}

Statistical analysis was performed by assessment of the mean (x), standard deviation (SD), and standard error of mean (SEM) values. Standard T-test was used for all analysis to assess differences between the groups. The results are expressed as mean $\pm \mathrm{SEM}$.

\section{RESULTS}

A total of 58 cows (19.46\%) were classified as having static ovaries (Fig. 1) and subjected to further analysis. The average period from calving until the start of the experiment were $72.17 \pm 2.22$ days,
$69.00 \pm 1.77$ days; $70.62 \pm 2.28$ days, $73.26 \pm 2.7$ days and $76.25 \pm 3.40$ days for SB 1.1, 1.2; 2.1, 2.2 and control group cows respectively. The mean serum concentrations of $\mathrm{P} 4$ in cows from all subgroups on $\mathrm{d}-7$ and $\mathrm{d} 0$ were $<0.5 \mathrm{ng} / \mathrm{mL}$ (data not shown).

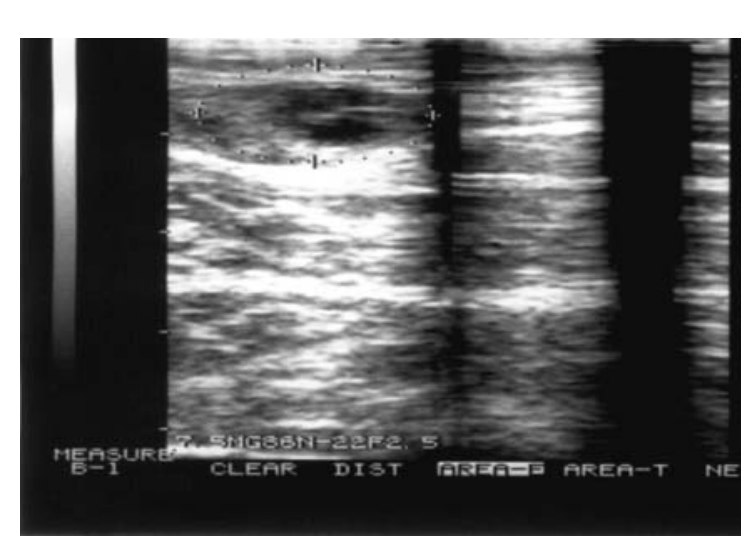

Figure 1. Ultrasound diagnose of static ovary (absent $\mathrm{CL}$, follicles $<8 \mathrm{~mm}$ )

Overall, the percentages of cows that established regular follicular growth (defined as continued development of the follicles) in GnRH Group 1, eCG Group 2, and the control group were $56.52 \%$ $(13 / 23), 60.86 \%(14 / 23)$ and $41.66 \%(5 / 12)$, whereas $43.47 \% \quad(10 / 23), 39.13 \% \quad(9 / 23)$ and $58.33(7 / 12)$ cows failed to respond and to resume follicular growth, respectively. Resumption of the follicular growth occurred in 86.6\% (13/15) SB 2.2 cows, $66.6 \%(10 / 15)$ in SB 1.2, $38.5 \%(3 / 8)$ in SB $1.1,12.5 \%(1 / 8)$ in SB 2.1 cows. The daily follicular growth rate was higher in SB $2.2(1.6 \pm 0.2 \mathrm{~mm} /$ day $)$ in comparison to the cows of the remaining $\mathrm{SB}$ $(1.1,1.2,2.1)$ being $(1.26 \pm 0.2 \mathrm{~mm} /$ day, $1.55 \pm 0.4$ $\mathrm{mm} /$ day, $1.3 \mathrm{~mm} /$ day) and the control group being $(0.8 \pm 0.2 \mathrm{~mm} /$ day $)$, respectively. Cows in the SB 2.2 experienced shorter $(5.7 \pm 0.2$ days $)$ treatment respond interval than cows in SB 1.1 1.2, and 2.1 ( $9 \pm 0.57$ days, $6.7 \pm 0.2$ days, and 8 days, respectively) and control group (17 \pm 0.7 days). Furthermore, ovulation occurred from the follicles which were larger in control group cows $(16.1 \pm 0.2 \mathrm{~mm})$ than cows in the SB $1.1(14.7 \pm 0.3 \mathrm{~mm}), \mathrm{SB} 1.2$ group $(15.6 \pm 0.2 \mathrm{~mm}), \mathrm{SB} 2.1(14.3 \mathrm{~mm})$ and SB 2.2 $(15.4 \pm 0.1 \mathrm{~mm})$. The diameter of the second largest follicle was higher in SB $2.2(11.7 \pm 0.2 \mathrm{~mm})$ than remaining SB as well as control group (SB 1.1 9.4 $0.3 \mathrm{~mm}, \mathrm{SB} 1.210 .2 \pm 0.2 \mathrm{~mm}, \mathrm{SB} 2.110 .5 \mathrm{~mm})$ and $8.4 \pm 0.2 \mathrm{~mm}$, respectively. Cows in SB 2.2 showed a higher rate $(42.85 \%)$ of multiple ovulations (defined as disappearance of the co-dominant follicles between two consecutive ultrasound examinations) 
in comparison with the cows in SB 2.1 (15.38\%) whilst no multiple ovulations were observed in the remaining subgroups.

Overall, there were not significant differences in the daily follicular growth rate between cows in both treatment groups ( $\mathrm{GnRH}$ vs eCG, $1.41 \pm 0.1$ $\mathrm{mm} /$ day vs. $1.45 \pm 0.1 \mathrm{~mm} /$ day, $\mathrm{p}>0.05)$. However, there was a significant difference compared to the control group $(1.41 \pm 0.1 ; 1.45 \pm 0.1 \mathrm{~mm} /$ day versus $0.8 \pm 0.2 \mathrm{~mm} /$ day, $\mathrm{p}<0.001)$. eCG Group 2 had a numerically faster treatment respond interval than GnRH Group 1 (6.85 \pm 0.2 days vs. $7.84 \pm 0.2$ days), but this was not significant $(\mathrm{p}>0.05)$. Moreover, both eCG and GnRH groups had significantly different treatment respond intervals than cows from the control group $(17 \pm 0.7$ days, $\mathrm{p}<0.001)$. Significant differences were observed between eCG, GnRH and control groups in the diameter of the second largest follicles being $11.5 \pm 0.3 \mathrm{~mm}, 9.9 \pm 0.2 \mathrm{~mm}$ and $8.4 \pm 0.2 \mathrm{~mm}$, respectively $(\mathrm{p}<0.05)$, with no differences between $\mathrm{GnRH}$ and controls $(\mathrm{p}>0.05)$. The average P4 concentrations on day 7 after ovulation were $3.91 \pm 0.6 \mathrm{ng} / \mathrm{ml}, 3.63 \pm 0.4 \mathrm{ng} / \mathrm{ml}, 4.32 \pm 0.5 \mathrm{ng} / \mathrm{ml}$ in Group 1, Group 2 and the control group, respectively but no differences were recorded $(\mathrm{p}>0.05)$. which correspondents with the data in the literature $19 \%$ (23); $13 \%$ (16).

Treatment with GnRH was followed by the establishment of regular folliculogenesis in 56.52\% of the cows. Similarly, when postpartum anestrous cows were treated with $\mathrm{GnRH}, 50 \%$ of those cows resume cyclic activity (19). We suggest that the reduced ovarian response is likely due to lack of LH receptors on granulosa cells (35). Acquisition of the LH receptors has been shown to occur near the selection of the future dominant follicle when the follicle reaches a size of around $8.5 \mathrm{~mm}$ (10). Therefore, the presence or absence of the selected dominant follicle at the time of treatment with $\mathrm{GnRH}$ apparently determines the success of the resumption of the cyclicity (5). Although systemic administration of $\mathrm{GnRH}$ causes increased $\mathrm{LH}$ concentration within 2-4 h (32), the latter has been shown to result in reduced response to the subsequent progress of the follicles if this increase occurs before the selection (29). Contrary, if the dominant follicle is already selected, it becomes increasingly responsive to $\mathrm{LH}$ and will continue to grow (5). The eCG has both FSH and LH like activity dominantly follicle-stimulating activity, (26); thus parenteral administration stimulates follicular growth and ovulation in cattle (22).

Table 1. Difference between GnRH, eCG and control group cows. Asterisks indicate significant differences between groups

\begin{tabular}{lccc}
\hline & GnRH & eCG & Control \\
\hline Daily growth rate (mm/day) & $1.41 \pm 0.10$ & $1.45 \pm 0.10$ & $* 0.8 \pm 0.2$ \\
$\begin{array}{l}\text { Differences between second } \\
\text { largest follicle (mm) }\end{array}$ & $9.9 \pm 0.2$ & $11.5 \pm 0.3^{* *}$ & $8.4 \pm 0.2$ \\
$\begin{array}{l}\text { Treatment respond interval } \\
\text { (days) }\end{array}$ & $7.84 \pm 0.20$ & $6.85 \pm 0.2$ & $17.0 \pm 0.7^{* * *}$ \\
Mean $\mathrm{P}_{4}(\mathrm{ng} / \mathrm{ml})$ & $3.91 \pm 0.60$ & $3.63 \pm 0.40$ & $4.32 \pm 0.50$ \\
Multiple ovulation & $15.38 \%$ & $42.85 \%$ & 0.00 \\
\hline
\end{tabular}

\section{DISCUSSION}

The present study compared the effects of single GnRH or eCG injection on the resumption of ovarian cyclicity in true postpartum anestrous cows. In order to initiate treat postpartum anestrous cows for early establishment of cyclic activity and the possibility of conception, the importance of identifying anestrous cows could lead to increased reproductive efficiency in the herd (7). By implementing transrectal ultrasonography accompanied with P4 assay, approximately $20 \%$ of the cows were diagnosed as being in true anestrous, 174
Our results have shown that $60.86 \%$ of the treated cows resumed cyclicity after eCG treatment which is in agreement with the results reported by Mansoor et al. (19). In that study $83.3 \%$ of the cows establish cyclicity when treated with eCG similarly as subgroup $2.2(86.6 \%)$. The increased response in the current study was achieved using smaller doses of 1000 IU than the dose used in the study of Mansoor et al. (3000 IU eCG) (19). When 1500 IU eCG was used, resumption of follicular growth occurred in $83.3 \%$ of the treated cows (9) which also correspond with the results observed in the present study. 
Furthermore, our results have shown that administration of $250 \mu \mathrm{g}$ GnRH or $1000 \mathrm{IU}$ eCG causes increased ovarian response when compared to lower applied doses $(100 \mu \mathrm{g}$ GnRH and $750 \mathrm{IU}$ eCG). This could lead to assumption that smaller doses of GnRH and eCG may have partially effect of the initiation of the follicular growth in cows with inactive ovaries. However, it should be noted that, in the early postpartum period, most of the cows are unable to meet their energy requirements as a result of decreased feed intake at a time when energy requirements are increasing (31). Therefore, an early pospartum cows enter a period of negative energy balance (NEB) which usually demises after 60 days postpartum (8). Cows in NEB have reduced genes expression in granulosa cell for LH receptors as well as having suppressed pulsatile LH secretion. This in turn causes a reduced ovarian response to LH stimulation (for reviews see Diskin et al.) (6). Therefore, it can be assumed that cows (especially in the subgroups 1.1 and 2.1) might still be in negative energy balance during the experiment and hence had a decreased treatment response.

The daily follicular growth rate did not differ between $\mathrm{GnRH}$ and eCG, $(1.41 \pm 0.1 \mathrm{~mm} /$ day vs. $1.45 \pm 0.1 \mathrm{~mm} /$ day), respectively. However, cows from both treatment groups significantly differed from the cows in the control group $(0.8 \pm 0.2 \mathrm{~mm} /$ day $)$. At the moment there is a lack of data in the literature, although these results could support the hypothesis of insufficient secretion of gonatrophins (3), necessary for enhanced resumption of the ovarian activity. In the current study eCG treated cows showed numerically faster treatment respond interval in comparison to GnRH (6.85 \pm 0.2 days vs. $7.84 \pm 0.5$ days respectively) and both GnRH and eCG treated cows significantly differed from the control group $(17 \pm 0.7$ days $)$. The faster eCG response in comparison to GnRH could be a consequence of the different mode of action of these hormones. Imperfection of the specific receptors for $\mathrm{GnRH}$ on the ovaries, demonstrate that its primary effect is on pituitary, stimulating pulsate release of FSH and LH in peripheral circulation (4). On the contrary, dominantly follicle-stimulating activity of eCG directly affects follicles and causes stimulation of folliculogenesis (26).

Due to the increased representation of multiple ovulations $(42.85 \%)$ in the eCG treated cows, despite having higher follicular growth rate and faster treatment respond interval, the treatment with eCG, cannot be suggested as method of choice for treatment of static ovaries in dairy cows. However, this treatment can be recommended in the beef cows where high rate of twinning is more desirable
(15). Similar rates, (47\% multiple ovulations) were observed by Musssard et al. (19) pointing that the reason might be result of follicular development during the presence of low progesterone concentration in the absence of CL. It has been shown that $\mathrm{CL}$ absent cows has increased plasma estradiol concentration compared to CL present cows (13). The latter could increase LH frequency which probably is involved in the growth of the second largest follicle leading to co-dominance (13). On the other hand, dominantly follicle-stimulating activity as well as the long half-life of eCG (5-7 days) (27), may lengthen the common growth phase of recruited follicles thereby disrupting the deviation process and subsequently allowing development of multiple dominant follicles.

\section{CONCLUSION}

The results of this study revealed several conclusions. First, ultrasound examination in cows more than 60 days after calving, accompanied by serum $\mathrm{P} 4$ determination is a reliable method for detecting the static ovaries. Second, the single application of eCG or GnRH enhanced the folliculogenesis through the processes of emergence, selection and dominance and re-establishment of cyclic activity, although the treatment success depends primarily on the energy status of the cow. Third, the eCG response is faster and more successful compared to GnRH, however, due to the increased occurrence of multiple ovulation and the possibility of higher twinning rate, this treatment method should be used without AI. Therefore as a general conclusion, single application of $250 \mu \mathrm{g}$ $\mathrm{GnRH}$ is an acceptable treatment method for static ovaries in terms of encouraging and reestablishing normal follicular growth concomitantly with the possibility of subsequent artificial insemination.

\section{REFERENCES}

1. Adams, G.P., Matteri, R.L., Kastelic, J.P., Ko, J.C.H., Ginther, O.J., (1992). Association between surges in follicle-stimulating hormone and emergence of follicular waves in heifers. J. Repro. Fert.94, 177-188. http://dx.doi.org/10.1530/jrf.0.0940177

2. Armstrong, D.G., Webb, R. (1997). Ovarian follicular dominance: the role of intra-ovarian growth factors and novel proteins. Rev. Repro. 2, 139-146. http://dx.doi.org/10.1530/ror.0.0020139 
3. Arthur, H. G., Noakes, D.E., Pearson, H. (1989). Veterinary reproduction and obstetrics. Theriogenology, Sixth edition W.B Saunders, Toronto.

4. Brown, J. L., Reeves, J. J. (1983). Absence of specific luteinizing hormone releasing hormone receptors in ovine, bovine and porcine ovaries. Biol. Reprod. 29, 1179-1182.

http://dx.doi.org/10.1095/biolreprod29.5.1179 PMid:6317071

5. Diskin, M.G., Austin, E.J., Roche, J.F. (2002). Exogenous hormonal manipulation of ovarian activity in cattle. Dom. Anim. Endo. 2, 211-228. http://dx.doi.org/10.1016/S0739-7240(02)00158-3

6. Diskin, M.G., Mackey, D.R., Roche, J.F., Sreenan, J.M. (2003). Effects of nutrition and metabolic status on circulating hormones and ovarian follicle development in cattle. Anim. Repro. Sci. 78, 345-370.

http://dx.doi.org/10.1016/S0378-4320(03)00099-X PMid:12818653

7. Dovenski T., Kocoski, Lj., Trojacanec, P., Popovski, K., Mickovski, G., Petkov, V., Veselinovic, S., Ivkov, V., Ivancev, N., Ickov, R., Mickov, Lj. (2000). Ultrasound diagnosis of functional ovarian disorders in dairy cows and its adequate treatment. Proceedings Symposium on veterinary clinical pathology and therapy "Clinica Veterinaria”, 35-50. Budva (in Serbian).

8. Drackley, J. K., Dann, H. M., Douglas, G. N., Guretzky, N.A. J., Litherland, N. B., Underwood, J.P., Loor, J. J. (2005). Physiological and pathological adaptations in dairy cows that may increase susceptibility to periparturient diseases and disorders. Ital. J. Anim. Sci. 4, 323-344.

9. Gabor, Gy., Kastelic, JP., Pinter, S., Szasz, F., Szigeti, E., Solymosi N. (2002). Improving reproductive performance in lactating dairy cows by synchronizing ovulation or inducing oestrus. Acta Vet. Hung. 50 (2), 231-234.

http://dx.doi.org/10.1556/AVet.50.2002.2.12

10. Ginther, O.J., Beg. M.A., Donadeu, F.X., Bergfelt, D.R. (2003). Mechanism of follicle deviation in monoovular farm species. Anim. Reprod. Sci. 78, 239-257.

http://dx.doi.org/10.1016/S0378-4320(03)00093-9

11. Ginther, O.J., Kastelic, J.P., Knopf, L. (1989). Compositions and characteristics of follicular waves during the bovine estrous cycle. Anim. Reprod. Sci. 20, 187-200.

http://dx.doi.org/10.1016/0378-4320(89)90084-5
12. Gümen, A., Guenther, J.N, Wiltbank, M.C. (2003). Follicular size and response to ovsynch versus detection of estrus in anovular and ovular lactating dairy cows. J. Dairy Sci. 86, $3184-3194$. http://dx.doi.org/10.3168/jds.S0022-0302(03)73921-6

13. Hayashi Ken-Go, Motozumi Matsui, Takashi Shimizu, Natsuko Sudo, Ayako Sato, Koumei Shirasuna, Masa Tetsuka, Katsuya Kida, Dieter Schams, Akio Miyamoto. (2008). The absence of corpus luteum formation alters the endocrine profile and affects follicular development during the first follicular wave in cattle. Reproduction 136, 787-797. http://dx.doi.org/10.1530/REP-07-0480 PMid:18715982

14. Jolly, P. D., McDougall, S., Fitzpatrick, L. A., Macmillan, K. L., Entwistle, K. W. (1995). Physiological effects of undernutrition on postpartum anoestrus in cows. J. Reprod. Fertil. Suppl. 49, 477-492.

PMid:7623336

15. Lopez, H., Caraviello, D. Z., Satter, L. D., Fricke, P. M., Wiltbank, M. C. (2005). Relationship between level of milk production and multiple ovulations in lactating dairy cows. J. Dairy Sci. 88, 2783-2793.

http://dx.doi.org/10.3168/jds.S0022-0302(05)72958-1

16. Lopez-Gatius, F., Lopez-Bejar, M., Rutllant, J., Yaniz, J., Santolaria, P. (1999). Persistent follicles in high-producing dairy cows. Proc EETA Annual Meeting, 190 abst., Lyon, France.

17. Lopez-Gatius, F., Santolaria, P., Yaniz, J., Ruthant, J., Lopez-Bejar, M. (2001). Persistent ovarian follicles in dairy cows: a therapeutic approach. Theriogenology, 56, 649-659. http://dx.doi.org/10.1016/S0093-691X(01)00596-9

18. Lucy, M. C., McDougall, S., Nation, D. P. (2004). The use of hormonal treatments to improve the reproductive performance of lactating dairy cows in feedlot or pasture-based management systems. Anim. Reprod. Sci. 82-83, 495-512.

http://dx.doi.org/10.1016/j.anireprosci.2004.05.004 PMid:15271476

19. Mansoor, A. R., Taha, M. M., Ahmed, K. D., Majeed, A. F. (2011). Treatment of inactive ovaries in dairy cows. Al-Anbar. J. Vet. Sci., 4, 1.

20. Moore, K., Thatcher, W. W. (2006). Major advances associated with reproduction in dairy cattle. J. Dairy Sci. 89, 1254-1266.

http://dx.doi.org/10.3168/jds.S0022-0302(06)72194-4 
21. Mussard, ML., Burke, CR.,Behlke, EJ., Gasser, CL., Day, ML. (2007). Influence of premature induction of a luteinizing hormone surge with gonadotropinreleasing hormone on ovulation, luteal function, and fertility in cattle. J. Anim. Sci. 85, 937-943.

http://dx.doi.org/10.2527/jas.2006-592

PMid:17145968

22. Newcomb, R., Christie, W.B., Rowson, L.E.A., Walters, D.E., Bousfield, W.E.D., (1979). Influence of dose, repeated treatment and batch of hormone on ovarian response in heifers treated with PMSG. J Reprod Fertil., 56, 113-118. http://dx.doi.org/10.1530/jrf.0.0560113

23. Opsomer, G,. Coryn, M., Deluyker, H., de Kruif, A. (1998). An analysis of ovarian dysfunction in high yielding dairy cows after calving based on progesterone profiles. Reprod Domest Anim., 33. http://dx.doi.org/10.1111/j.1439-0531.1998.tb01342.x

24. Opsomer, G., Mijten, P., Coryn M., de Kruif, A. (1996). Post-partum anoestrus in dairy cows: a review. Vet Quart., 18, 68-75.

http://dx.doi.org/10.1080/01652176.1996.9694620 PMid:8792599

25. Opsomer G.(2013). High yielding dairy cows: to produce or to reproduce and what practitioners should know about this to help their clients. Mac Vet Rev; 36 (2): 53-62.

26. Popovski, K., Kanchev, Lj. (1998). Endocrinology of reproduction. First Ed. Veterinaren institut i Veterinaren fakultet, Skopje

27. Pulley, S.L., Wallace, L.D., Mellieon, H. I. Jr., Stevenson, J.S. (2013). Ovarian characteristics, serum concentrations of progesterone and estradiol, and fertility in lactating dairy cows in response to equine chorionic gonadotropin. Theriogenology 79 , 127-134.

http://dx.doi.org/10.1016/j.theriogenology.2012.09.017 PMid:23131466

28. Rhodes, F. M., McDougall, S., Burke, C. R., Verkerk, G. A., Macmillan, K. L. (2003). Treatment of cows with an extended postpartum anestrous interval. J. Dairy Sci. 86, 1876-1894.

http://dx.doi.org/10.3168/jds.S0022-0302(03)73775-8
29. Ryan, M, Mihm, M, Roche, J.F. (1998). Effect of GnRH given before or after dominance on gonadotrophin response and the fate of that follicle wave in postpartum dairy cows. J. Reprod. Fertil. Abstr Ser, 21, 61.

30. Santos, J.E.P., Rutigliano, H.M., Sá Filho, M.F. (2009). Risk factors for resumption of postpartum cyclicity and embryonic survival in lactating dairy cows. Anim. Reprod. Sci. 110, 207-221.

http://dx.doi.org/10.1016/j.anireprosci.2008.01.014 PMid:18295986

31. Santos, JEP. (2011). Nutritional management of lactating dairy cows, dairy production medicine. John Wiley \& Sons, Inc., Ames, IO, USA

32. Smith, M.F., Perry, G.A., Atkins, J.A., Jinks, E.M., Pohler, K.G., Patterson, D.J. (2010). Physiological principles underlying synchronization of estrus. Appl. Reprod. Strat. Conf. Proc. August $5 \& 6$ Nashville, TN, USA

33. Townson, D.H., Tsang, P.C., Butler, W.R., Frajbla, M., Griel, L.C. Jr., Johnson, C.J., Milvae, R.A., Niksic, G.M., Pate, J.L. (2002). Relationship of fertility to ovarian follicular waves before breeding in dairy cows. J Anim. Sci. 80, 1053-1058. PMid:12008660

34. Wiltbank, M.C., Gumen, A., Sartori, R. (2002). Physiological classification of anovulatory conditions in cattle. Theriogenology 57, 21-52. http://dx.doi.org/10.1016/S0093-691X(01)00656-2

35. Xu, Z.Z., Garverick, H.A., Smith, G.W., Smith, M.E., Hamilton, S.A., Youngquist, R.S., (1995). Expression of follicle stimulating hormone and luteinizing hormone receptor messenger ribonucleic acids in bovine follicles during the first follicular wave. Biol. Reprod., 52, 464-469.

36. Zdunczyk, S., Mwaanga, E.S., Tepicht, M.J., Baranski, W., Janowski, T. (2002). - Plasma progesterone levels and clinical findings in dairy cows with post-partum anoestrus. Bull.Vet.Inst. Pulawy 46, 79-86. 